\title{
PERBEDAAN BERAT (gram) BIBIT KERANG MUTIARA (Pinctada Maxima) ANTAR WARNA CANGKANG DI PERAIRAN TEKALOK LOMBOK TIMUR NTB
}

\author{
Syachruddin AR. ${ }^{1}$, Abdul Syukur ${ }^{1}$, Septy Suryaningsih ${ }^{2}$ \\ ${ }^{1}$ Dosen Pendidikan Biologi PMIPA FKIP UNRAM \\ ${ }^{2}$ Mahasiswa Pendidikan Biologi PMIPA FKIP UNRAM \\ E-maill : dinar_bima@yahoo.co.id
}

Diterima: 20 Maret 2018. Disetujui: 24 April 2018. Dipublikasikan: 14 Mei 2018

\begin{abstract}
Abstrak
Bibit kerang mutiara jenis Pinctada maximamemiliki berbagai macam warna cangkang, tetapi yang lebih menonjol, adalah : warna coklat, warna kuning, warna hitam dan warna putih. Berat bibit kerang mutiara berdasarkan warna cangkangnya bervariasi. Hasil penelitian tentang berat bibit menurut kelompok warna, menunjukkan bahwa: berat dan variasi beratnya, adalah : Warna Coklat (0,564 gram dengan variasi 0,010); Warna Kuning $(0,557$ gram dengan variasi 0,012$)$; Warna Hitam $(0,565$ gram dengan variasi $0,054)$ dan Warna Putih $(0,575$ gram dengan variasi 0,013$)$. Hasil analisis statistik menunjukkan bahwa : perbedaan berat bibit antar kelompok warna tidak signifikan, karena $\mathrm{F}_{\text {hitung }}(1,436)<\mathrm{F}_{\text {tabel }}(2,608)$ dan nilai $\mathrm{P}(0,230)<\mathrm{P}_{\text {critikal }}(2,608)$. Hasil penelitian ini menunjukkan bahwa: pertumbuhan berat bibit kerang mutiara antar kelompok warna tidak ada perbedaannya, namun berdasarkan reratanya bibit yang berwarna putih cenderung lebih berat dibandingkan dengan bibit yang berwarna lainnya dengan urutan berat, sebagai berikut: Putih $(0,575$ gram $)>\operatorname{Hitam}(0,565$ gram $)>\operatorname{Coklat}(0,564$ gram $)>$ Kuning (0,557gram).
\end{abstract}

Kata kunci : bibit, warna cangkang, berat dan variasi.

\begin{abstract}
Cockle pearl seed Pinctada maxima species owning assorted ofcolour of shell but more uppermost, is : brown yellowcolour, black colour and white colour. Heavy of pearl cockle seed pursuant to the colour of him vary. Result of research concerning seed weight according to colour group, indicating that: wt. variation and weight, is : Brown ( 0,564 gram with variation of 0,010); Yellow Colour(0,557gram with variation [of] 0,012); Black Colour ( 0,565 gram with variation [of] 0,054) and White Colour $(0,575$ gram with variation of 0,013). Statistical analysis result show that : heavy difference of seed between colour group do not isn't it, because $F_{\text {count }}(1,436)<F_{\text {table }}(2,608)$ and value of $P$ $(0,230)<\mathrm{P}_{\text {critikal }}(2,608)$. This Research result indicate that: heavy growth of pearl cockle seed between colour group there no difference of him, but pursuant to the average of seed which was white chromatic tend to compared to heavier of seed which is other chromatic with heavy sequence, as follows: White ( 0,575 gram > Black ( 0,565 gram > Brown ( 0,564 gram > Yellow $(0,557$ gram $)$.
\end{abstract}

Key word : seed, colour of shell, heavy and variation. 


\section{PENDAHULUAN}

Kerang mutiara jenis Pinctada maxima merupakan salah satu komoditas perikanan laut yang bernilai ekonomi tinggi dan memiliki prospek pengembangan usaha pada masa mendatang. Syachruddin (1990), mengemukakan bahwa proses kehidupan kerang mutiara dapat dimanfaatkan untuk memproduksi mutiara dengan bentuk dan warna yang sangat indah sehingga dimanfaatkan oleh manusia untuk membuat perhiasan dalam bentuk cincin, kalung, dan giwang bagi kaum perempuan.Daging merupakan sumber protein yang sangat tinggi. Di samping itu, kulit dan mutiara yang dihasilkannya dapat dimanfaatkan untuk bahan kosmetik dan bahan dasar pembuatan cat metalik.

Pada awalnya mutiara hanya diperoleh dari kerang mutiara alam, tetapi berkat kemajuan ilmu pengetahuan dan teknologi maka kerang mutiara saat ini dapat dibudidayakan untuk menghasilkan mutiara, namun sebagian besar ilmu dan teknologinya masih dikuasai oleh teknisi dari Jepang. Kerang mutiara jenis Pinctada maximayang dibudidayakan saat ini merupakan jenis kerang penghasil mutiara terbaik yang dikenal juga dengan Mutiara Laut Selatan (South Sea Pearls). Kerang mutiara jenis ini lebih banyak terdapat di perairan Indonesia terutama perairan Indonesia bagian timur.Harga mutiara jenis South Sea Pearl (SSP) pergramnya menurut Arief, dkk., (2012) untuk kualitas terbaik berkisar antara Rp300.000 - Rp.1.000.000.-

Pengusaha budidaya kerang mutiara di Indonesia memproduksi butiran mutiara budidaya, karena mutiara alam sulit ditemukan lagi. Populasi kerang mutiara di alam saat ini mengalami penurunan karena perubahan kondisi alam yang ekstrim dan kemampuan kerang mutiara untuk meningkatkan jumlah populasinya semakin berkurang dan sulit untuk ditemukan. Di samping itu, penurunan jumlah populasi kerang mutiara disebabkan oleh eksploitasi yang tidak memperhatikan kelestarian populasi (overfishing). Faktor inilah menurut Syachruddin (2006), merupakan penyebab menurunnya jumlah kerang yang diinsersio oleh para pengusaha mutiara sehingga produksi mutiara tidak dapat ditingkatkan kuantintas dan kualitasnya secara kontinyu.

Permintaan mutiara di pasar yang terus meningkat,mendorong pengusaha mutiara untuk mengeksploitasi bibit kerang mutiara secara berlebihan dan tidak berimbang dengan kemampuan kerang mutiara untuk meningkatkan jumlah populasinya di alam. Pengusaha mutiara membutuhkan bibit kerang sebaanyak mungkin untuk operasi penyisipan inti (Yosmer, 1999). Bibit kerang mutiara yang dibutuhkan berukuran di atas $6 \mathrm{~cm}$ dengan harga sekitar Rp 2.000/cm, setelah berukuran antara $8-10 \mathrm{~cm}$ akan dilakukanoperasi penyisipan inti sehinggaperusahaan mebutuhkan bibit yang banyak untuk operasi penyisipan inti sampai ratusan ribu ekor bibit tiap tahunnya.

Menghadapi situasi yang demikian sangatlah bijak apabila pengusaha melakukan pembibitan dan kegiatan pemeliharaan untuk mendapatkan bibit agar tidak melakukan eksploitasi yang berlebihan. Pembesaran bibit kerang mutiara oleh masyarakat sekitar akan membantu penyediaan bibit untuk kebutuhan penyisipan inti oleh perusahaan sekaligus akan mengurangi tingkat kemiskinan bagi masyarakat sekitar 
perusahaan.Peningkatan produksi atau produktivitas bibit kerang mutiara oleh pengusaha melalui kegiatan pembibitan dan pendederan atau pembesaraan bibit kerang mutiara mendorong pengusaha agar produksi mutiara tetap berkelanjutan(Anonim, 2013a).Menyadari betapa besarnya potensi mutiara yang kita miliki maka Balai Budidaya Perikanan dan Kelautan Indonesia selalu berupaya untuk meningkatkan ilmu dan teknologi tentang usaha budidaya kerangmutiara. Syachruddin (2005), menyatakan bahwa keberhasilan Balai Budidaya Perikanan dan Kelautan untuk membudidayakan kerang mutiara di Indonesia menunjukan bahwa teknologi itu dapat dikuasai dan diterapkan oleh bangsa Indonesia.

Perairan NTB menurut Syachruddin (2006), terdapat beberapa perusahaan budidaya kerang mutiara yang akan menampung bibit dari masyarakat sehingga pemasaran bibit hasil produksi masyarakat tidak mengalami kesulitan. Apabila kegiatan pembibitan dilakukan secara terencana dan terstruktur. Efektivitas dan efisiensi pengadaan bibit akan memberikan dampak yang positif terhadap peningkatan kesejahteraan rakyat. Menurut Arief dkk., (2012), cara demikian akan menjamin kesinambungan produksi mutiara di NTB sebagai komoditas unggulan Perikanan dan Kelautan. Di samping itu, Syachruddin (2006), menyatakan bahwa bibit kerang mutiara yang diproduksi harus terjamin kuantitas dan kualitas serta kontinuitasnya agar produksi mutiara tetap berkelanjutan.

Kerang mutiara jenis Pinctada maxima hidup dengan baik di perairan
Indonesia terutama di perairan: Nusa Tenggara Barat, Nusa Tenggara Timur, Sulawesi Tenggara (Kendari) dan Maluku (Anonim, 2013b). Walaupun masih ada usaha pencarian bibit dan mutiara di alam tetapi kebanyakan bibit dan mutiara yang dipasarkan saat ini adalah hasil budidaya. Mengingat begitu potensialnya mutiara untuk kebutuhan manusia sehingga Jepang sebagai negara yang pertama kali melakukan budidaya adalah orang Jepang (Mikimoto) maka Jepang menurut (Syachruddin,2014a) tetap menjaga kerahasiaannya sampai akhir tahun 80-an dan mengembangkan usahanya ke negaranegara lain pada kawasan pasifik dan lautan Hindia seperti di Indonesia, namun Jepang tetap melibatkan teknisinya dalam usaha budidaya.

Hasil observasi dan penelitian yang dilakukan oleh (Syachruddin, 1999), ternyata bibit kerang mutiara pada perusahaan budidaya di NTB ditemukan warna cangkang dan mantel yang bermacam - macam, antara lain : warna coklat, warna hitam, warna kuning dan warna putih. Warna cangkang dan warna mantel bibit kerang mutiara, menurut Syachruddin (1997a) dapat dijadikan sebagai indikator untuk memprediksi warna mutiara yang akan diproduksi terutama kerang mutiara yang akan dijadikan donor mantel dalam penyisipan inti (nukleus). Pemilihan bibit berdasarkan warna merupakan salah satu usaha untuk meningkatkan kualitas mutiara yang akan dihasilkan. Warna cangkang bibit kerang mutiara dapat dilihat pada gambar (di bawah). 


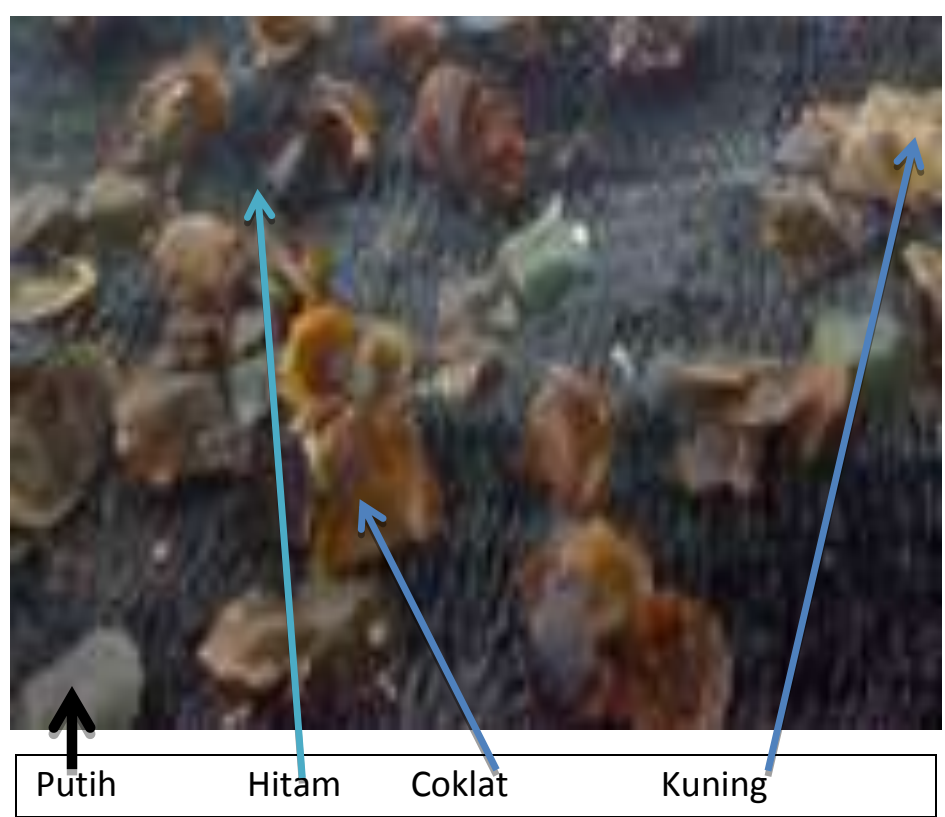

Gambar 1 : Pemilihan bibit berdasarkan warna.

Warnacangkangdan matel merupakan salah satu indikator kualitas bibit dari kerang mutiara.Pemilihan warna bibit yang tepat dan berkualitas tinggi akan menentukan warna dan kualitas mutiara yang akan dihasilkan dalam usaha budidaya. Warna bibit Kerang mutiara jenis Pinctada maxima menurut Syachruddin (1997a) ada 4 macam, yaitu :putih, hitam, coklat, dan kuning, masih ada beberapa warna, namun secara mendasar tetap dikelompokkan dalam keempat warna tersebut. Populasi bibit kerang mutiara berdasarkan warna cangkangnya ditemukan hampir merata untuk semua perusahaan di perairan NTB. Peningkatan kebutuhan bibit dari perusahaan akan mendorong eksploitasi bibit yang berlebihan di alam. Meningkatkan kemampuan reproduksi kerang mutiara pada tiga fase utama dalam perkembangannya akan membantu meningkatkan jumlah bibit untuk memenuhi kebutuhan kebutuhan perusahaan. Fase perkembangannya yang perlu diperhatikan adalah: a) fase perkembangan gonad; b) fase pemijahan dan fertilisasi; c) fase pertumbuhan dan perkembangan. Peningkatan pertumbuhan dan perkembang pada fase tersebut menurut Syachruddin (1997b) merupakan salah satu solusi untuk meningkatkan jumlah bibit sehingga eksploitasi bibit di alam dapat dikurangi. Bibit kerang mutiara dari pemijahan yang berbeda menunjukkan tahapan perkembangan larva (metamorfosis) dan pertumbuhan yang berbeda. Bibit yang dihasilkan melalui pemijahan dari 2 populasi yang berbeda keragamannya lebih baik dibandingkan dengan bibit hasil pemijahan dari populasi yang sama. Bibit hasil pemijahan dari perkawinan antar 2 populasi yang berbeda memiliki tingkat kelangsungan hidup (SR) $>30 \%$ pada tiap pergantian stadia dan waktu pergantian stadia (metamorfosis), yaitu : lebih cepat 2/3 hari dari yang lainnya (Ida, dkk., 2014). Kecepatan pertumbuhan dan metamorfosis bibit kerang mutiara tergantung dari pakannya karena menurut Yeni, dkk. (2004), pakan yang disukai oleh bibit kerang mutiara jenis Pinctada maxima adalah Tetraselmis $s p$ dengan 
konsentrasi pakan $20.000 \mathrm{sel} / \mathrm{ml}$ dan kecepatan filtrasi mencapai 1,63 liter/jam. Hasil penelitian ini menunjukkan konsentrasi terbaik untuk kecukupan pakan bibit kerang mutiara jenis Pinctada maxima adalah $60.000 \mathrm{sel} / \mathrm{ml}$ dengan kecepatan filtrasi mencapai 1,29 liter/jam.

\section{BAHAN DAN METODE}

Bahan : bibit kerang mutiara jenis Pinctada maxima dan alkohol;

Alat : Speed Boad, Timbangan, Loupe atau kaca pembesar, Pocket/Waring net, Pisau silet atau pisau lipat.

Metode: Tempat pemeliharaan bibit dan penimbangannya: Perairan Tekalok Lombok Timur (bekerja sama dengan PT.Bumi). Bibit kerang mutiara dipelihara/digantung pada long line dengan interval 5 meter untuk tiap lapisan kedalaman, yaitu : Lapisan Atas (5 m); Lapisan Tengah (10 m); Lapisan bawah (15 m) pada kedalaman air sekitar 25 meter berlangsung selama 2 bulan dan tiap kelompok warna dipelihara secara acak pada tiap lapisan kedalaman.

1. Lokasinya dapat dilihat pada peta Lokasi berikut :

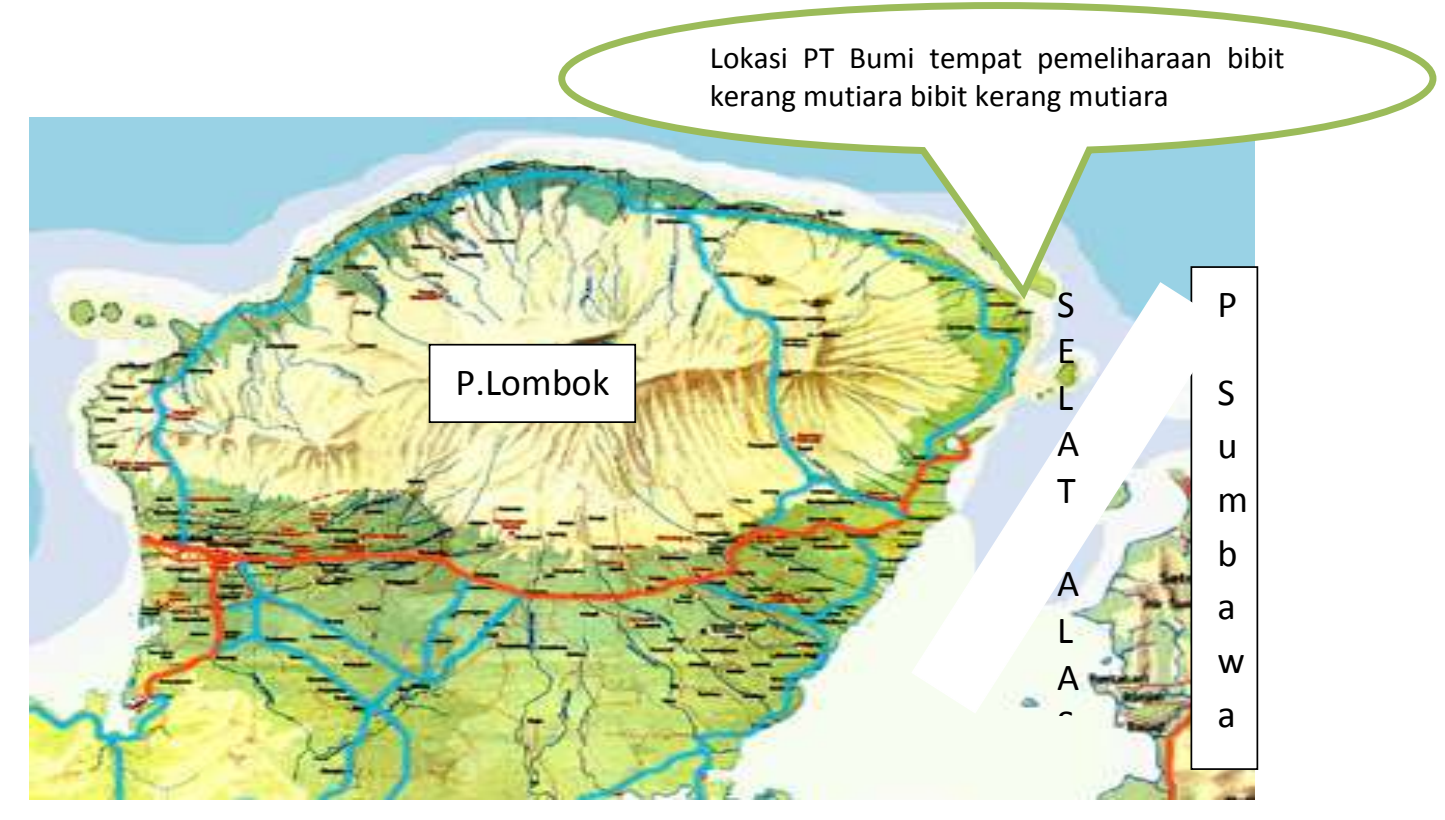

Gambar 2 : Peta pulau Lombok sebagai lokasi PT Bumi tempat pemeliharaan bibit kerang mutiara. 
2. Teknik Pemeliharaan/penggantungan pada long line dapat dilihat pada skema berikut:

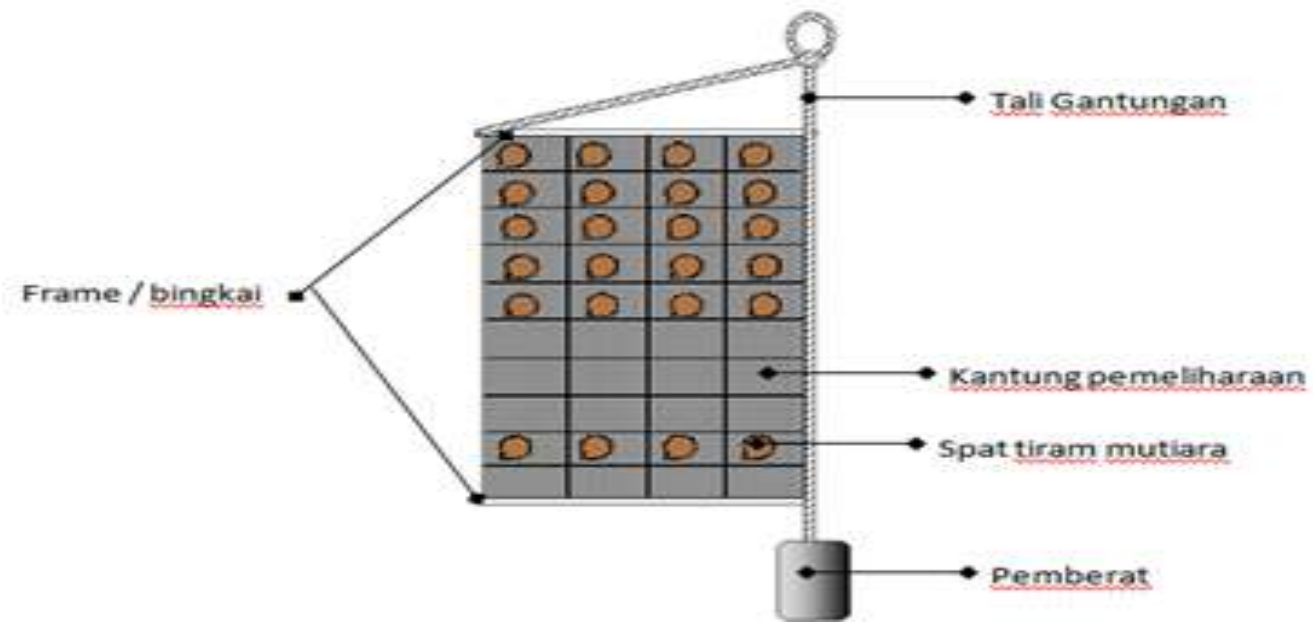

3. Teknik Penimbangan Bibit kerang mutiara

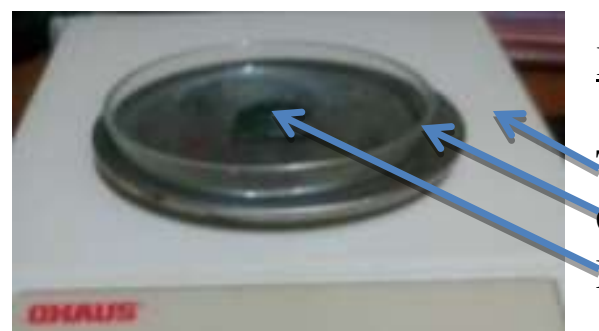

$\underline{\text { Keterangan : }}$

Timbangan elektrik

Cawan petri

Bibit kerang yang ditimbang

4. Teknik Analisis data danAnalisis statistik menurut Sutrisno (2000), dapat menggunakan SPS $_{12}$ (SPS Sutrisno Hadi, seri - 2000).

\section{HASIL DAN PEMBAHASAN}

\section{Hasil}

Hasil penelitian tentang berat (gram) tiap kelompok warna cangkang pada bibit kerang mutiara jenis Pinctada maximapembahasannya berdasarkan analisis statistik yang berpedoman pada hasil analisis data dan analisis statistik yang menggunakan $\operatorname{SPS}_{12}$ (SPS Sutrisno
Hadi, seri - 2000) darihasil penimbangan berat (gram) bibit kerang mutiara tiap kelompok warna, dengan ketentuan bahwa nilai $<1,00_{\text {(homogen) }}$ dan $\geq 1,00_{\text {(heterogen) }}$ hasilnya dapat dilihat padaTabel 1 (hasil analisis data)dan Tabel 2 (hasil analisis statistik).

Tabel 1. Hasil analisis data tentang berat bibit berdasarkan warna cangkang pada kerang mutiara jenis Pinctada maxima di perairan Tekalok Lombok Timur.

\begin{tabular}{|c|c|c|c|c|c|}
\hline No & $\begin{array}{c}\text { Warna } \\
\text { Cangkang }\end{array}$ & $\begin{array}{c}\text { Jumlah } \\
\text { (ekor) }\end{array}$ & $\begin{array}{c}\text { Berat } \\
\text { (gram) }\end{array}$ & $\begin{array}{c}\text { Rata-rata } \\
\text { (gram) }\end{array}$ & $\begin{array}{c}\text { Variasi } \\
\text { berat }\end{array}$ \\
\hline 1. & Coklat & 840 & 473,900 & 0,564 & 0,010 \\
\hline 2. & Kuning & 1058 & 589,000 & 0,557 & 0,012 \\
\hline 3. & Hitam & 1044 & 589,500 & 0,565 & 0,054 \\
\hline 4. & Putih & 430 & 247,200 & 0,575 & 0,013 \\
\hline
\end{tabular}


Bibit kerang mutiara jenis Pinctada maxima yang berwarna coklat sebanyak 840 ekor dengan total beratnya 473.900 gram(rata-rata 0,564 gram/ekor dan variasi berat 0,010). Bibit yang berwarna kuning sebanyak 1.058 ekor dengan total berat 589.000 gram (rata-rata berat 0,557 gram dan variasi beratnya
0,012). Bibit berwarna hitam sebanyak 1.044 ekor dengan total berat 589.500 gram (rata-rata berat 0,565 dan variasi berat 0,054). Bibit berwarna putih sebanyak 430 ekor dengan total berat 247.200 gram (rata-rata berat 0,575 dan variasi berat 0,013). Gambaran hasilnya dapat dilihat juga pada grafik berikut.

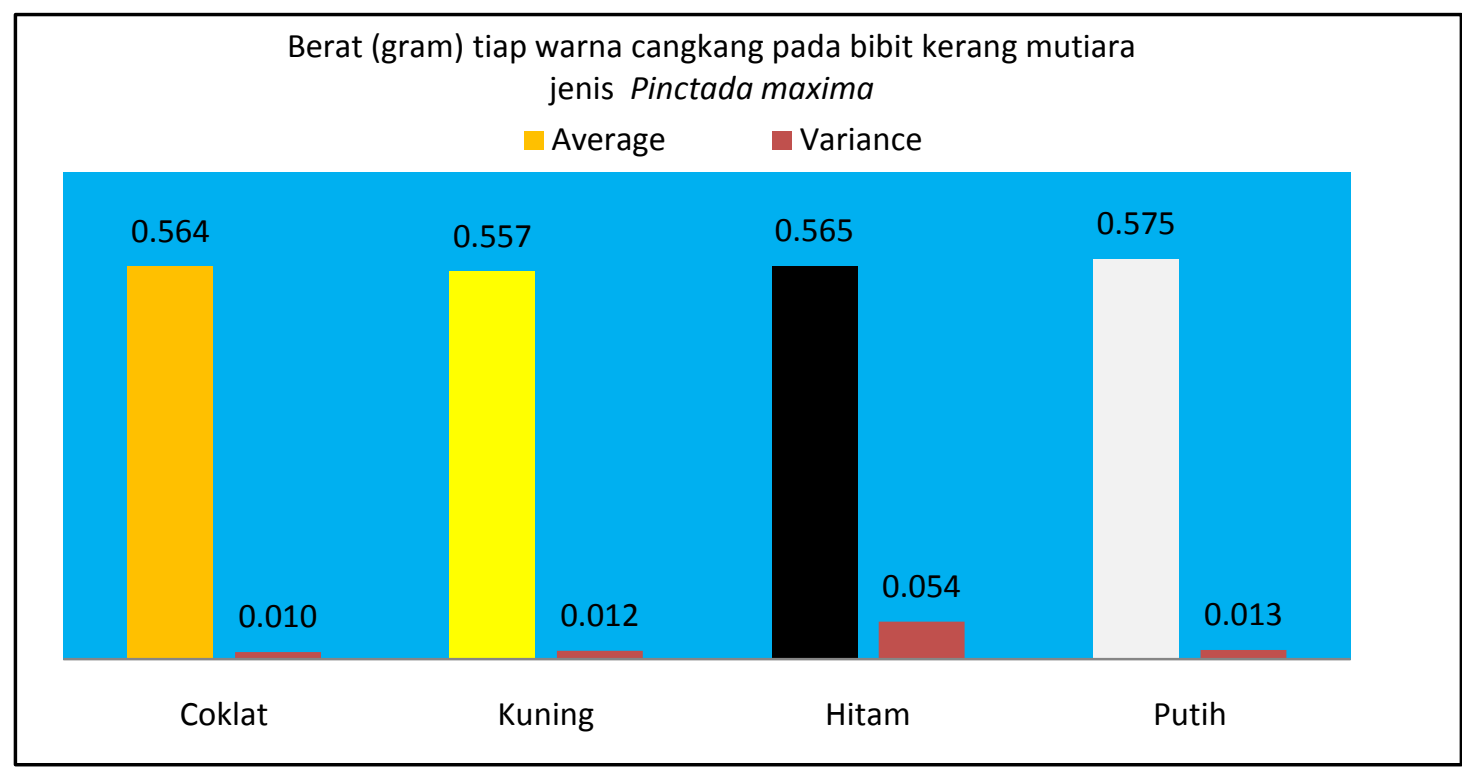

Berat bibit tiap warna perbedaannya tidak signifikan dengan variasi berat yang berada dibawah ratarata 0,1 ini menunjukkan bahwa berat bibit relatif merata untuk tiap kelompok warna cangkang, terutama variasi berat dalam kelompoknya.Analisis statistik tentang berat bibit tiap kelompok warna, hasilnya dapat dilihat pada Tabel 2 berikut :

Tabel 2. Hasil analisis statistik tentang perbedaan berat bibit kerang mutiara (Pinctada maxima) tiap kelompok warna di Tekalok Lombok Timur

\begin{tabular}{|l|r|r|r|r|r|l|}
\hline \multicolumn{1}{|c|}{ Source of Variation } & \multicolumn{1}{c|}{ SS } & \multicolumn{1}{c|}{$d f$} & MS & $F$ & P-value & $F$ crit \\
\hline Between Groups & 0,106 & 3 & 0,035 & 1,436 & 0,230 & 2,608 \\
\hline Within Groups & 83,023 & 3.368 & 0,025 & & & \\
\hline Total & 83,129 & 3.371 & & & & \\
\hline
\end{tabular}

Hasil analisis statistik menunjukkan bahwa nilai $\mathrm{F}_{\text {hitung }}(1,436)$ lebih kecil $(<)$ dari $\mathrm{F}_{\text {tabel }}(2,608)$ demikian juga nilai probabilitasnya (nilai $\mathrm{P}=0,230$ lebih kecil $\left.(<) \mathrm{P}_{\text {critikal }}=2,608\right)$. Berarti berat bibit tiap kelompok warna perbedaannyatidak signifikan, namun berat bibit tiap kelompok warna berdasarkan rerata kecenderungannya bahwa bibit yang berwarna putih $(0,575$ gram) lebih berat dibandingkan dengan bibit yang berwarna lainnya. Secara kongkrit dapat dilihat pada grafik tentang perbedaannya, berartiberat bibit kerang 
mutiara jenis Pinctada maxima di perairan Tekalok Lombok Timur NTB pertambahan beratnya merata untuk semua bibit (homogen).

Berat bibit kerang mutiara jenis Pinctada maxima tiap kelompok warna variasinya sangat rendah $(\mathrm{P}=0,230)$ berarti pertumbuhan bibit pada semua kelompok warna (coklat, kuning, hitam, dan putih) di perairan Tekalok Lombok Timur dilihat dari berat dan variasinya untuk semua kelompok warna secara statistik perbedaannya tidak signifikan.

\section{Pembahasan}

Kerang mutiara memiliki prospekyang sangat baik untuk dibudidayakan sebagai salah satu komoditas unggulan perikanan di Indonesia. Mengingat potensi dan prospek pengembangan yang sangat baik maka Unit Pelaksana Teknis (UPT) Perikanan Budidaya Laut di Indonesia terus berusaha untuk mengembangkan program breeding (pembibitan). Program ini secara kontinyu harus dilakukan agar kebutuhan bibit untuk insertio dapat dipenuhi dan ditingkatkan. Hasil pembibitan (breeding) melalui budidaya memiliki keunggulan tersendiri antara lain : kecepatan pertumbuhan bibit tiap kelompok breeding pertumbuhannya homogen. Syachruddin $\left(2014_{b}\right)$ menyatakan bahwa homogenitas pertumbuhan bibit merupakan salah satu indikator untuk memprediksi mutiara yang akan dihasilkan, seperti : warna, ukuran dan besar mutiara yang akan dihasilkan oleh suatu perusahaan sehingga tiap kelompok warna bibit akan menghasilkan mutiata dengan warna, yang sama walaupun kemungkinan bentuk dan ukuran mutiara yang dihasilkan berbeda.
Berdasarkan warna cangkang (shell) dapat dijadikan sebagai salah satu indikator untuk prediksi kualitas bibit dan mutiara yang akan dihasilkan oleh setiap kelompok warna. Menurut Syachruddin (1997a), bahwa warna cangkang dan warna mantel dapat dijadikan sebagai dasar untuk menentukan kualitas dan warna mutiara yang akan dihasilkan. Bibit kerang mutiara secara morfologis dapat ditentukan kualitasnya melalui indikator warna, berat, ukuran (panjang dan lebar) serta tebal dari kulitnya. Syachruddin (2005), menyatakan bahwa bibit yang lebih berat, panjang dan lebar serta tebal dan warnanya tidak pucat berarti sehat dan kualitasnya baik dan dapat menghasilkan mutiara yang berkualitas tinggi.

Pemilihan bibit yang berkualitas sangat penting untuk dilakukan oleh semua pengusahadengan cara, antara lain : pengusaha antar daerah melakukan pertukaran bibit (crosing over), misalnya, bibit dari perairan NTT dipelihara di perairan NTB atau sebaliknya, demikian juga bibit dari perairan NTB dipeliharadi perairan Kendari bahkan ke perairan Sumatra. Crosing over semacam ini dapat meningkatkan daya adaptasi dan kualitas bibit kerang mutiara bahkan mutiara yang akan dihasilkan.

Eksploitasi yang berlebihan berupa pengambilan bibit kerang mutiara dari alam, akan merusak ekosistem dan mengurangi populasinya. Pemanfaat bibit kerang mutiara hasil budidaya dengan warna yang berbeda dan berat yang hampir sama akan mendukung produksi mutiara budidaya yang berkuatas lebih baik, mandiri dan berkelanjutan.Pembudidayaan bibit harus ditingkatkan karena akan membantu meningkatkan populasi kerang mutiara di 
alam melalui restocking akan menjaga kelestarian populasi kerang mutiara di alam dan masyarakat semakin sejahtera sehingga usaha budidaya kerang mutiara akan terus berjalan (Anonim, 2016).Di samping itu, para pembudidaya kerang mutiara tidak akan tergantung dari bibit alami sehingga populasi kerang mutiara di alam tetap terjaga kelestariannya.

Hasil analisis statistik menunjukkan bahwa nilai $\mathrm{F}_{\text {hitung }}(1,436)$ lebih kecil $(<)$ dari $F_{\text {tabel }}(2,608)$ demikian juga nilai probabilitasnya (nilai $\mathrm{P}=0,230$ dan $\mathrm{P}_{\text {critikal }}=2,608$ ). Berarti berat bibit tiap kelompok warna menunjukkan perbedaan yang tidak signifikan, namun berat bibit tiap kelompok warna kecenderungannyabahwa bibit yang berwarna putih $(0,575 \mathrm{~cm})$ yang lebih berat dibandingkan dengan berat bibit yang berwarna lainnya. Secara kongkrit dapat dilihat pada grafik tentang perbedaan berarti berat bibit kerang mutiara jenis Pinctada maxima di Tekalok Lombok Timur Nusa Tenggara Barat.

Berat bibit kerang mutiara jenis Pinctada maxima tiap kelompok warna menunjukkan bahwa variasinya sangat rendah berarti kecepatan pertumbuhanberdasarkan indikator beratnya hampir sama untuk semua kelompok warna, berarti perbedaannya tidak signifikan sesuai dengan nilai $\mathrm{F}$ $(1,436)$ dan nilai Probabilitas (P) lebih kecil $(<)$ dari nilai $\mathrm{F}_{\text {tabel }}(2,608)$.

Teknis Budidaya Kerang Mutiara pada prinsipnya, untuk dalam keberhasilan pemeliharaan bibit kerang mutiara untuk menghasilkan mutiara bulat baik kualitas maupun kuantitas sangat ditentukan oleh proses penanganan bibit kerang mutiara sebelum operasi pemasangan inti, pelaksanaan operasi, pemeliharaan pasca operasi dan ketrampilan dari teknisi serta sarana pembenihan bibit kerang mutiara yang memadai (Anonim, 2013 ). Pemeliharaan bibit kerang mutiara harus memperhatikan kondisi perairannya.

Pemeliharaan bibit (juvenil) yang masih kecil berukuran dibawah $5 \mathrm{~cm}$ dilakukan penggantungan pada kedalaman 2- 3 m sedangkan bibit dengan ukuran 5 $\mathrm{cm}$ ke atas dipelihara pada kedalaman lebih dari $5 \mathrm{~m}$. Syachruddin (1990),menyatakan bahwa makin dalam penggantungan untuk pemeliharaan kerang mutiara makin tebal kulit/nakrenya (lapisan mutiara) sehingga berat mutiara semakin meningkat dan mutiara yang akan dihasilkan semakin baik kualitasnya.Peningkatan kualitas maupun kuantitas mutiara yang diproduksi akan meningkatkan nilai ekonomi dan kesejahteraan masyarakat bahkan PAD bagi pemerintah juga akan meningkat.

\section{KESIMPULAN}

Berat bibit kerang mutiara jenis Pinctada maximadi perairan Tekalok Lombok Timur Nusa Tenggara Barat berdasarkan kelompok warna perbedaannya tidak signifikan dengan variasi berat yang homogen, namun : berdasarkan reratanya bibit yang berwarna putih cenderung lebih berat dibandingkan dengan bibit kerang yang berwarna lainnya dengan urutan berat : Putih $(0,575$ gram $)>$ Hitam $(0,565$ gram $)>$ Coklat $(0,564$ gram $)>$ Kuning (0,557gram) dengan rata-rata variasi berat lebih kecil dari 1,0. Berarti pertumbuhan bibit kerang mutiara berdasarkan kelompok warna hampir sama (homogen). 


\section{DAFTAR PUSTAKA}

Anonim (2013a). Teknologi Tepat Guna (Cara Budidaya Tiram Mutiara). Balai Budidaya Laut, Direktorat Jendral Perikanan, Departemen Pertanian, Lampung. (http://teknologi-tepat-gunablogspot.com/2013/04)

Anonim, (2013b). Kerang Mutiara Sumbar Berkualitas Internasional. Divisi Teknologi Informasi Classy FM@2012. All rights reserved. 21 Mei 2013.

Anonim, (2016). Dukung Pengembangan Budidaya Kerang Mutiara Berkelanjutan. Kantor Kelautan dan Perikanan (KKP) Bantuan Benih Dari UPT Lingkup DJPBData Bantuan Direktorat Kawasan 2016 Update 25 Oktober 2016. Profil, Direktorat, Download, Akuntabilitas, Layanan Publik, Statistik, Link Lembaga. SESDITJEN, DIREKTORAT.

Hakim AR dan Prabowo T, (2012). Kajian Teknis Dan Analisis Usaha Produksi Budidaya Kerang Mutiara Air Laut (Pinctada Maxima) Penghasil Butir Mutiara Air Laut Lombok The South Sea Pearl. Lombok Barat, 30 Oktober 2012.

Ida Komang Wardana dkk, (2014). Profil Benih Tiram Mutiara (Pinctada maxima) Dari Hasil Pemijahan yang Terkontrol. Balai Besar Penelitian dan Pengembangan Budidaya Laut Gondol. PO.BOX. 140 Singaraja Bali 81101. Jurnal Oseanologi Indonesia Vol.1, No.1, Maret 2014.
Syachruddin, AR., (1990). Kualitas Biologik, Kimia dan Fisik Perairan Pesisir dan Kaitannya dengan Pertumbuhan Tiram Mutiara (Pinctada sp) di Tanjung Bero Sumbawa, Nusa Tenggara Barat. Tesis untuk memperoleh gelar Magister pada FPS-UGM Yogyakarta.(belumdipublikasikan)

Syachruddin, AR., (1997a). Warna Cangkang Bibit Kerang mutiara jenis Pinctada maxima di NTB. (Laporan Penelitian survey bibit kerang mutiara pada PT. Selat Alas, PT. Bumi, PT. Aneka Mutiara dan PT. Paloma Agung di Nusa Tenggara Barat). Kerjasama dengan PT. Bumi Indonesia.

Syachruddin, AR., (1997b). Analisis Hormon LH dan FSH Kerang mutiara jenis Pictada maxima. Laporan penelitian pendahuluan disertasi berjudul Stimulasi Hormonal Untuk Memacu Pemijahan Kerang mutiara. Program Pascasarjana Universitas Airlangga Surabaya (belum dipublikasikan)

Syachruddin, AR., (1999). Stimulasi Hormonal Untuk Memacu Pemijahan Kerang Mutiara (Pinctada maxima). Disertasi untuk memperoleh gelar Doktor pada Program Pasca Sarjana Universitas Airlangga Surabaya (belum dipublikasikan).

Syachruddin AR., Drs., MS. Dr., (2005). Perairan Laut NTB Menyimpan Biota Komoditas Unggulan Eksport. Dosen Biologi PMIPA FKIP Universitas Mataram. Makalah seminar Nasional Kerang mutiara di Jakarta. 
Diselenggarakan oleh BAPENAS RI dalam rangka persiapan Studi Banding ke Eropah oleh LER (Local Economic Resource). September Tahun 2005.

Syachruddin AR.,(2006). Peningkatan Produksi Mutiara Melalui Usaha Pembesaran Bibit Kerang Mutiara Di Perairan Kota Bima NTB. Dosen Biologi PMIPA FKIP Universitas Mataram.(Makalah Seminar Bapenas Program Local Economic Resources Development (LERD). Jakarta, 20 September 2006.

Syachruddin, AR., (2014a). Sejarah Perkembangan Mutiara. Jurnal Biotropis, volume 14 (1):45-51. 2 Januari 2014. ISSN 1411 - 9587.

Syachruddin, AR., (2014b). Penerapan Model Matematika dalam
Memprediksi keuntungan

Budidaya Kerang mutiara. Jurnal Penelitian Universitas Mataram, volume 2 (14) :83-90. Agustus 2008. EdisiA : Sains dan Teknologi. ISSN 0854 - 0098.

Sutrisno Hadi., (2000). Seri Program Statistik (SPS) versi 2000. Manual SPS Paket MIDI.Edisi : Prof. Sutrisno Hadi. Universitas Gadjah Mada tahun 2000.

Yeni Sulistiyani dkk (2004). Filtration Rate Tiram Mutiara Pinctada Maxima Dari Perairan Lombok, NTB. Ilmu Kelautan Universitas Diponegoro. Semarang, (E-mail: jennydata@yahoo.com.

Yosmer,(1999). Kerang mutiara Sumbar Berkualitas Internasional. Dinas Kelautan dan Perikanan Provinsi Sumatera Barat. 